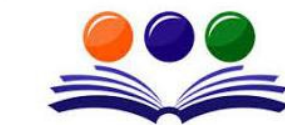

GRAND ACADEMIC PORTAL RESEARCH JOURNALS

\title{
YUKTAHAR (TEMPERANCE IN EATING): WITH REFERENCE TO SHRIMAD BHAGVAD GEETA
}

\begin{tabular}{c} 
Dr. Aruna Jadeja \\
Research Guide \\
Patel Prakash M., \\
Ph.D. Research Scholar \\
Lakulish Yoga University \\
Higher Studies and Research Academy \\
Chharodi, Gujarat, India \\
\hline \hline
\end{tabular}

Abstract

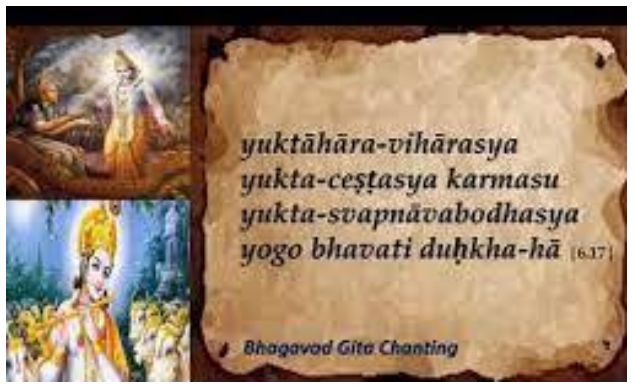

The term yoga is inclusive of all practices in yogas. Yet, Ashtanga Yoga, the yoga of eight-fold steps. is another name for Raaja Yoga. Sanatana Yoga, the eternal and universal yoga. is the most ancient one, as authenticated by the Vedas. After mastering it, Maharshi Patanjali wrote about it in 'Yogadarsana', which is also known as Patanjali's Yoga.

Yogadarsana follows the Saankhya system of philosophy and hence it has the knowledge concerned with the scriptures. It deals with the existence of God and His testimony as an example. It is also called the scripture of bhakti and the scripture of yoga as it teaches the eight-fold steps of yoga.

यमनियमासनप्राणायामप्रत्याहारधारणाध्यानमधयोष्टावडगानि // योगदर्शन-साधनपाद - 29

These eight-fold steps are:

Yam-Niyama

Aasan- Pranayama

Pratyahar- Dharna

Dhyan - Samadhi

The First Step To Yoga : Yama

First a seeker (Sadhak) must purify his body and mind through yoga (Sadhana). This alone is not enough. When he seriously starts this uphill task, he has to vividly know that Yama is designated as a mahavrata, a great vow. He has to ensure that no new impurities creep in.

Yama and niyama (restraints and observances) are aids to purification. They help to make the sadhana simpler. If they are neglected, many hurdles crop up during sadhana. It takes a long tune to up-root these evils. To save time and energy, it is necessary that one must resort to yama and niyama.

Yama and niyama build up an impregnable fort for Sadhana. A seeker has to erect a wall of yama to prevent the entry of forbidden acts in his life.

Yama is not bounded by race, country or time. Therefore, it can be practiced at any stage.

The above five disciplines are described in Yogadarsana. 


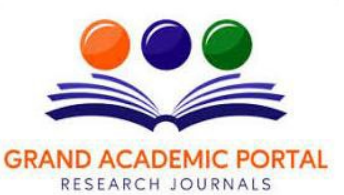

In the Hatha Yoga Pradipika there are ten disciplines:

"ahimsa, non-violence; satya, truth; asteya, non-stealing; brahmacarya, celibacy; ksama, forgiveness; dhrti, steadfastness; daya, compassion; arjava, straightforwardness;b sauca, cleanliness and Mitaahaar, moderate food." (DhyanVignan Swami Kripalvanndji, 2016, 49)

Last yama is Mitaahara (moderate food).

सुस्निण्धमधुराहारधतुच्थांशविव्रजितः ।

भुज्यते शिवसंप्रीत्यै मिताहारः स उच्यते // हठयोगप्रदीपिका // 58 //

"Eating a digestible and tasty meal for the love of God while leaving the stomach one-fourth empty enables mitahara. One has to take food for the objective of mastering yoga and not merely for the pleasure of eating. Overeating repels one from Sadhana (spiritual practice).

Fasting with proper worship and observances does purify both the body and the mind, but the results are not permanent. Furthermore, it weakens the body making it challenging to practice sadhana in its proper form. He, who practices mitahara with determination is forever in a proper fast." (Krupalu, 1977, 20)

In Niyama - Mitahar is connected to Yuktahar. Shrimad Bhagvadgeeta says regarding to Yuktahar as :

\section{युक्ताहारविहारस्य युक्तचेष्टस्य कर्मसु ।}

\section{युक्तस्वप्नावबोधस्य योगो भवति दुःखहा $\|6: 17\|$}

One who properly balances his diet, activity and works, his hours of sleeping and waking, gains this sorrowdestroying yoga (Jasol, 2021,62)

It means those who are temperate in eating and recreation, balanced in work, and regulated in sleep, can migrate all sorrows by practicing Yog.

Yog is the union of the soul with God. The opposite of Yog is bhog, which means engagement in sensual pleasures. Indulgence in bhog violates the natural laws of the body, and results in rog (disease).

As stated in the previous verse, if the body becomes diseased, it impedes the practice of Yog. Thus in this verse, Shree Krishna states that by being temperate in bodily activities and practicing Yog, we can become free from the sorrows of the body and mind.

The same instruction was repeated two-and-a-half millennium after Shree Krishna by Gautam Buddha, when he recommended the golden middle path between severe asceticism and sensual indulgence. There is a beautiful story regarding this. It is said that before gaining enlightenment, Gautam Buddha once gave up eating and drinking, and sat in meditation. However, after a few days of practicing in this manner, the lack of nourishment made him weak and dizzy, and he found it impossible to steady his mind in meditation. At that time, some village women happened to pass by. They were carrying water pots to fill water from a nearby river and were singing a song. The words of the song were: "Tighten the strings of the tānpurā (a stringed Indian musical instrument, resembling a guitar). But do not tighten them so much that the strings break." Their words entered the ears of Gautam Buddha, and he exclaimed, "These illiterate village women are singing such words of wisdom. They contain a message for us humans. We too should tighten our bodies (practice austerities), but not to the extent that the body is destroyed." (www.holy-bhagavad-gita.org)

Benjamin Franklin (1706 - 1790), a founding father of the United States, is highly regarded as a self-made man. In an effort to grow his character, starting at the age of 20, he maintained a diary in which he tracked his performance related to the 13 activities he wanted to grow in. The first activity was "Temperance: Eat not to dullness; drink not to elevation." (https://www.holy-bhagavad-gita.org 


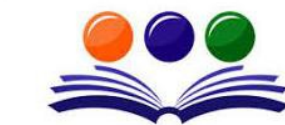

GRAND ACADEMIC PORTAL RESEARCH JOURNALS
GAP BODHI TARU

A GLOBAL JOURNAL OF HUMANITIES

( ISSN - 2581-5857)

Impact Factor: SJIF - 5.171, IIFS - 5.125

Globally peer-reviewed and open access journal.

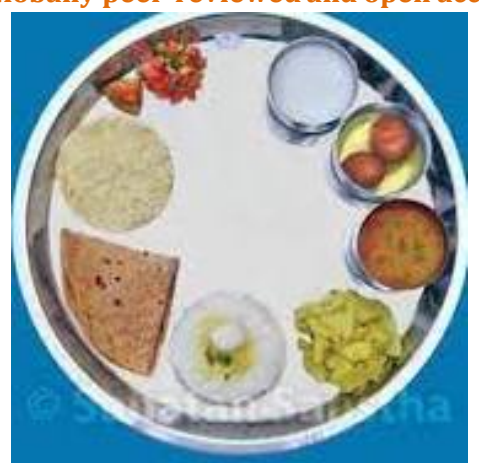

Shrimad Bhagvadgeeta also Mentioned,

आहारस्त्वपि सर्वस्य त्रिविधो भवति प्रिय:

यज्तस्तपस्तथा दानं तेषां भेदमिमं शृणु ॥ $17: 7 \|$

The food that a person prefers is according to their dispositions. The same is true for the sacrifice, austerity, and charity which they are incline towards. Now hear of the distinctions from me.

The mind and body impact each other. Thus, the food people consumed, influences their nature and vice versa. The Chhāndogya Upanișhad explains that the coarsest part of the food we eat passes out as feces; the subtler part becomes flesh; and the subtlest part becomes the mind (6.5.1). Again, it states: āhära śhuddhau sattva śhuddhi (7.26.2)[v1] "By eating pure food, the mind becomes pure." The reverse is also true-people with pure minds prefer pure foods.

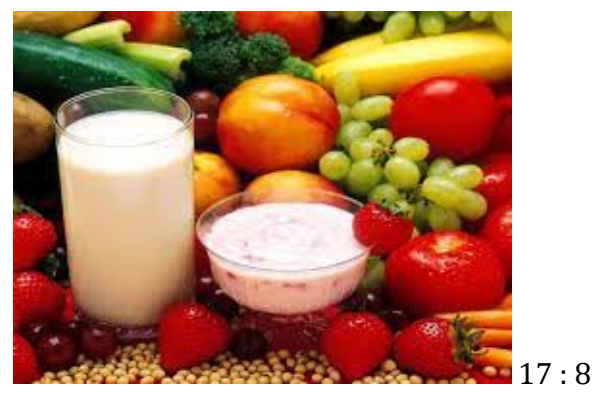

आयु:सत्तबलारोग्यसुखप्रीतिविवर्धना: ।

रस्या: स्निग्धा: स्थिरा हृद्या आहारा: सात्तिकप्रिया: ॥17:8\|

Person in the mode of goodness prefer foods that increases the life span, and enhances virtue, strength, health, happiness, and satisfaction. Such foods are juicy, succulent, nourishing, and naturally tasty.

In Chapter 14, verse 6, Shree Krishna had explained that the mode of goodness is pure, illuminating, and serene, and creates a sense of happiness and satisfaction. Foods in the mode of goodness have the same effect. In the above verse, these foods are described with the words āyuh sattva, meaning "which promote longevity." They bestow good health, virtue, happiness, and satisfaction. Such foods are juicy, naturally tasteful, mild, and beneficial. These include grains, pulses, beans, fruits, vegetables, milk, and other vegetarian foods.

Hence, a vegetarian diet is beneficial for cultivating the qualities of the mode of goodness that are conducive for spiritual life. Numerous sāttvic (influenced by the mode of goodness) thinkers and philosophers in history have echoed this sentiment:

"Vegetarianism is a greater progress. From the greater clearness of head and quicker apprehension motivated him to become a vegetarian. Flesh-eating is an unprovoked murder." - Benjamin Franklin, www.consumerfreedom.com 


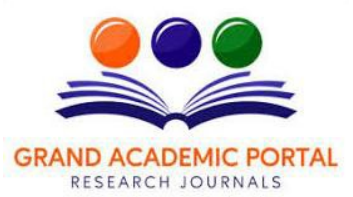

\section{GAP BODHI TARU A GLOBAL JOURNAL OF HUMANITIES}

( ISSN - 2581-5857)

Impact Factor: SJIF - 5.171, IIFS - $\mathbf{5 . 1 2 5}$

Globally peer-reviewed and open access journal.

"Is it not a reproach that man is a carnivorous animal? True, he can and does live, in a great measure, by preying on other animals; but this is a miserable way. I have no doubt that it is a part of the destiny of the human race, in its gradual improvement, to leave off eating animals, as surely as the savage tribes have left off eating each other when they came in contact with the more civilized." Henry David Thoreau in "Walden, https://www.holy-bhagavadgita.org/

"It is necessary to correct the error that vegetarianism has made us weak in mind, or passive or inert in action. I do not regard flesh-food as necessary at any stage." Mahatma Gandhi. chapter-4,

http://www.gandhiashramsevagram.org/

"O my fellow men, do not fill your bodies with sinful foods. We have corn and we have apples bending down the branches with their weight. There are vegetables that can be cooked and softened over the fire. The earth affords a lavish supply of riches, of innocent foods, and offers you banquets that involve no bloodshed or slaughter. Only beasts satisfy their hunger with flesh, and not even all of those, because horses, cattle, and sheep live on grass." Pythagoras, https://www.holy-bhagavad-gita.org/

and Bernard Shaw also states

"I do not want to make my stomach a graveyard of dead animals." George Bernard Shaw https://www.holybhagavad-gita.org/

Even amongst violence against animals, killing of the cow is particularly heinous. The cow provides milk for human consumption, and so it is like a mother to human beings. To kill the mother cow when it is no longer capable of giving milk is an insensitive, uncultured, and an ungrateful act.

कट्वम्ललवणात्युष्णतीक्ष्णरूक्षविदाहिन: ।

\section{आहारा राजसस्येष्टा दु:खशोकामयप्रदा: ॥17:9\|}

Foods that are too bitter, too sour, salty, very hot, pungent, dry, and spicy, are dear to persons in the mode of passion. Such foods produce pain, grief, and disease.

When vegetarian foods are cooked with excessive chilies, sugar, salt, etc. they become rājasic. Thus, rājasic foods are very bitter, very sour, very salty, very hot, very pungent, very dry, very spicy, etc. They produce ill-health, agitation, and despair. Persons in the mode of passion find such foods attractive, but those in the mode of goodness find them disgusting. The purpose of eating is not to relish bliss through the palette, but to keep the body healthy and strong. As the old adage states: "Eat to live; do not live to eat." Thus, the wise partake of foods that are conducive to good health, and have a peaceful impact upon the mind i.e., sāttvic foods.

\section{यातयामं गतरसं पूति पर्युषितं च यत् ।}

उच्छिष्टमपि चामेध्यं भोजनं तामसप्रियम् //17: 10//

yāta-yāmai் gata-rasam் pūti paryușhitam் cha yat

uchchhișhțam api chāmedhyam் bhojanaṁ tāmasa-priyam

yāta-yāmam—stale foods; gata-rasam—tasteless; pūti-putrid; paryushitam-polluted; cha-and; yat-

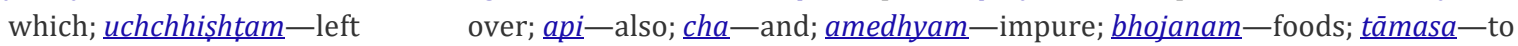
persons in the mode of ignorance; priyam-dear

yata-yamam gata-rasam puti paryushitam cha yat

uchchhishtam api chamedhyam bhojanam tamasa-priyam

Foods that are overcooked, stale, putrid, polluted, and impure are dear to persons in the mode of ignorance.

Cooked foods that has remained for more than one yām (three hours) are classified in the mode of ignorance. Foods that are impure, have bad taste, or possess foul smells come in the same category. Impure foods also include all kinds of meat products. Nature has designed the human body to be vegetarian. Human beings do not have long canine teeth as carnivorous animals do, or a wide jaw suitable for tearing flesh. Carnivores have short bowels to allow minimal transit time for the unstable and dead animal food, which putrefies and decays faster. On the contrary, humans have a longer digestive tract for the slow and better absorption of plant food. The stomach of carnivores is more acidic than human beings, which enables them to digest raw meat. Interestingly, the carnivorous animals do not sweat through their pores. Rather, they regulate body temperature through their tongue. On the other hand, herbivorous animals and humans control bodily temperature by sweating through 


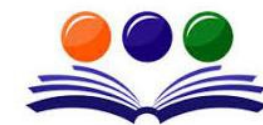

GRAND ACADEMIC PORTAL RESEARCH JOURNALS

\section{GAP BODHI TARU \\ A GLOBAL JOURNAL OF HUMANITIES}

( ISSN - 2581-5857)

Impact Factor: SJIF - 5.171, IIFS - 5.125

Globally peer-reviewed and open access journal.

their skin. While drinking, carnivores lap up water rather than suck it. In contrast, herbivores do not lap up water; they suck it. Humans too suck water while drinking; they do not lap it up. All these physical characteristics of the human body reveal that God has not created us as carnivorous creatures, and consequently, meat is considered as an impure food for humans.

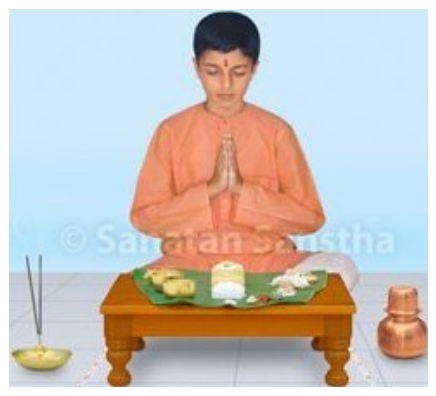

अन्न एवं परब्रह्म ।।

Meat-eating also creates bad karma. The 'Manu Smriti' states: mām sa bhakșhayitāmutra yasya māmsam ihādmy aham etan māmisasya māmsatvam pravadanti manīṣhiṇah (5.55)[v2]

"The word mānsa (meat) means "that whom I am eating here will eat me in my next life." For this reason, the learned say that meat is called mānsa (a repeated act: I eat him, he eats me)."

Hence, Yuktahar is a very important factor in practcing yog including it in daily life routine and also to vanish all sorrows, as Geetaji says.

\section{Ref :}

Hathyog Pradeeipika, Swami Kripalavanandji, Krupalu Munimandal, 2017

Science of Meditation, Swami Kripalavanandji, Krupalu Munimandal, 1977

Dhyanvignan, Swami Kripalavanandji,, Krupalu Munimandal, 1977

Shrimad Bhagvadgeeta, F. Jasol, Notion Press Private Ltd 2021

www.holy-bhagavad-gita.org 